\title{
PENGARUH RETURN ON INVESTMENT (ROI), EARNING PER SHARE (EPS) DAN ECONOMIC VALUE ADDED (EVA) TERHADAP RETURN SAHAM PADA PERUSAHAAN OTOMOTIF YANG TERDAFTAR DI BEI PADA TAHUN 2013-2016
}

\author{
Oktavianti \\ Prodi Manajemen, Fakultas Ekonomi, Universitas Riau kepulauan \\ vianti_310@yahoo.com
}

\begin{abstract}
ABSTRAK
Penelitian ini dilakukan untuk mengetahui : (1) Untuk menganalisis Return On Investment (ROI) berpengaruh terhadap return saham perusahaan otomotif yang terdaftar di Bursa Efek Indonesia. (2) Untuk menganalisis Earning Per Share (EPS) berpengaruh terhadap return saham perusahaan otomotif yang terdaftar di Bursa Efek Indonesia. (3) Untuk menganalisis Economic Value Added (EVA) berpengaruh terhadap return saham perusahaan otomotif yang terdaftar di Bursa Efek Indonesia. (4) Untuk menganalisis Return On Investment (ROI), Earning Per Share (EPS) dan Economic Value Added (EVA) secara simultan berpengaruh terhadap Return Saham perusahaan Otomotif yang terdaftar di Bursa Efek Indonesia.Penelitian ini merupakan jenis kuantitatif karena di dalamnya mengacu pada perhitungan data penelitian yang berupa angka-angka. Variable penelitian ini meliputi variable dependen dan independen. Sampel dalam penelitian ini adalah Perusahaan Otomotif yang terdaftar di Bursa Efek Indonesia (BEI) periode 2013-2016. Pemilihan sampel menggunakan metode purposive sampling, dengan jumlah 11 perusahaan selama periode 2013-2016. Teknik analisis data menggunakan Uji Asumsi Klasik, Analisis Regresi Linier Berganda dan Uji Hipotesis. Analisis ini dilakukan dengan menggunakan program SPSS 20. Penelitian ini menunjukkan bahwa variable Return On Investment (ROI), Earning Per Share (EPS) dan Economic Value Added (EVA) secara parsial tidak berpengaruh terhadap return saham, sedangkan secara simultan tidak berpengaruh secara signifikan terhadap return saham.

Kata Kunci : Return On Investment (ROI), Earning Per Share (EPS) dan Economic Value Added (EVA), Return Saham.
\end{abstract}

\section{PENDAHULUAN}

Industri otomotif Indonesia telah menjadi sebuah pilar penting dalam sector manufaktur negara ini karena banyak perusahaan mobil yang terkenal di dunia membuka pabrikpabrik manufaktur mobil atau meningkatkan kapasitas produksinya di Indonesia, negara dengan ekonomi terbesar di Asia Tenggara. Saat ini Indonesia sangat tergantung pada investasi asing langsung, terutama dari jepang, untuk mendirikan fasilitas manufaktur mobil. Indonesia juga 


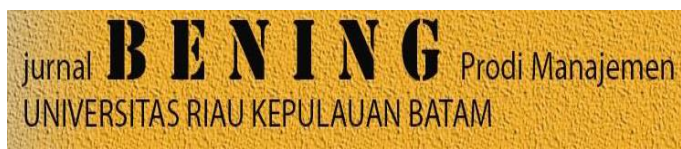

perlu mengembangkan industry komponen mobil yang bisa mendukung industry manufaktur mobil. Saat ini, kapasitas total produksi mobil yang dirakit di Indonesia berada pada kira-kira dua juta unit per tahun. Per 2017 kapasitas total produksi terpasang mobil di Indonesia adalah 2,2 juta unit per tahun. Industry otomotif di Indonesia mengalami peningkatan dari tahun ke tahun. Maka dari itu banyak calon investor yang ingin membeli saham di industry otomotif. Saham merupakan surat berharga yang bersifat kepemilikan. Artinya si pemilik saham merupakan pemilik perusahaan.

Seseorang Investor yang akan melakukan investasi dalam bentuk saham, selalu memperhitungkan hasil dari return yang akan diperolehnya. Investor tersebut akan memperoleh dua bentuk pendapatan yang diinginkan yaitu capital gain dan pendapatan deviden (deviden yield). Semakin besar yield maka investor akan semakin tertarik untuk membeli saham tersebut . Investor akan terlebih dahulu mencari informasi untuk memastikan apakah investasi tersebut akan memberikan tingkat pengembalian yang diharapkan dan seberapa besar resiko yang akan dihadapi. Dari laporan keuangan, seorangInvestor dapat mengetahui bagaimana kondisi perusahaan dan kinerja manajemen perusahaan tersebut.. Penggunaan analisa rasio keuangan sangat bervariasi dan tergantung oleh pihak yang memerlukan. Analisa laporan keuangan dalam penelitian ini digunakan rasio profitabilitas yaitu return on investment (ROI) dan earning per share (EPS). Selain itu
Volume 5 No. 2 Tahun 2018

P-ISSN 2252-5262

E-ISSN 2614-499

ada metode analisis lain yaitu dengan Economic Value Added (EVA).

Return On Investment (ROI) adalah hasil bagi antara laba bersih dengan total investasi yang ditanamkan pada aktiva perusahaan. ROI adalah analisis rasio keuangan yang penting karena sifatnya menyeluruh, jadi ROI digunakan untuk menilai tingkat efektivitas perusahaan secara keseluruhan. Oleh karena itu, rasio ini membandingkan laba setelah bunga dan pajak yang diperoleh perusahaan dengan jumlah aktiva yang digunakan untuk memperoleh laba tersebut. Semakin besar nilai ROI, maka kinerja perusahaan meningkat. Investor akan tertarik untuk berinvestasi di perusahaan yang memiliki kinerja yang meningkat, sehingga harga saham perusahaan tersebut akan mengalami peningkatan.

$$
\text { Earning Per Share (EPS) }
$$

adalah tingkat keuntungan yang diperoleh pemegang saham dalam tiap lembar saham yang dimiliki. EPS didapat dari laba bersih setelah bunga dan pajak dibagi dengan jumlah saham biasa yang beredar. Informasi yang terdapat di dalam EPS menggambarkan besarnya jumlah laba bersih perusahaan setelah bunga dan pajak yang dibagikan kepada para pemegang saham. Nilai EPS yang semakin tinggi, akan meningkatkan minat para investor untuk berinvestasi. Semakin banyak jumlah investasi yang dilakukan maka perusahaan akan mengalami peningkatan harga saham, dan akan memberikan tingkat return saham yang tinggi. EPS dapat dihitung dengan membandingkan laba bersih yang diperoleh perusahaan dengan jumlah saham yang beredar. EPS memengaruhi return saham 


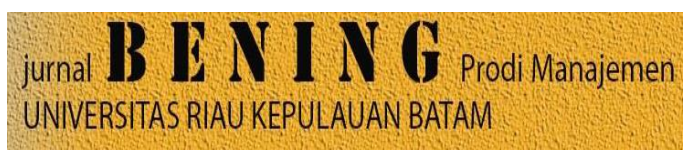

perusahaan yang ditandai dengan

kemampuan perusahaan dalam memperoleh keuntungan.

EVA atau Economic Value Added merupakan suatu konsep baru yang dikembangkan dalam menjelaskan hubungan antara nilai perusahaan dengan return saham. EVA adalah aktivitas manajeman yang menghasilkan nilai tambah ekonomis. EVA dalam sebuah perusahaan akan menjadi indikator tambahan nilai dari semua aktivitas-aktivitas yang dilakukan oleh perusahaan yang dapat meningkatkan nilai serta memangkas kegiatan yang tidak efektif. EVA yang positif mencerminkan bahwa perusahaan telah sukses memberikan nilai bagi pemodal dan pasar karena tingkat pengembalian perusahaan jauh lebih tinggi daripada biaya modalnya. Perusahaan yang memiliki tujuan untuk memakmurkan pemegang saham, indikator sering dikaitkan dengan kinerja perusahaan harus mempunyai korelasi dengan return yang didapatkan pemegang saham.

Kajian terhadap industri otomotif yang mengalami perkembangan yang pesat perlu dilakukan untuk mengetahui pengaruh Return On Investment (ROI), Earning Per Share (EPS), dan Economic Value Added (EVA) terhadap return saham. Kondisi perusahaan otomotif yang mengalami perkembangan pesat akan memicu ketertarikan investor pada pihak perusahaan karena nilainya yang telah meningkat, serta fenomena yang ada di masyarakat karena permintaan atas produknya meningkat. Peran investor disini sangatlah berpengaruh dalam investasinya terhadap suatu perusahaan, khususnya perusahaan otomotif.
Volume 5 No. 2 Tahun 2018

P-ISSN 2252-5262

E-ISSN 2614-499

Berdasarkan latar belakang tersebut di atas, maka peneliti tertarik untuk mengadakan penelitian dengan judul :"Pengaruh Return On Investment (ROI), Earning Per Share (EPS) Dan Economic Value Added (EVA) Terhadap Return Saham Perusahaan Otomotif Yang Terdaftar Di Bursa Efek Indonesia".

\section{TUJUAN PENELITIAN}

Tujuan penelitian ini adalah sebagai berikut :

a. Untuk mengetahui pengaruh Return On Investment (ROI) terhadap return saham perusahaan otomotif yang tercatat di Bursa Efek Indonesia periode 2013-2016.

b. Untuk mengetahui pengaruh Earning Per Share (EPS) terhadap return saham perusahaan otomotif yang tercatat di Bursa Efek Indonesia periode 2013-2016.

c. Untuk mengetahui pengaruh Economic Value Added (EVA) terhadap return saham perusahaan otomotif yang tercatat di Bursa Efek Indonesia periode 2013-2016.

d. Untuk mengetahui secara simultan pengaruh Return On Investment, Earning Per Share, dan Economic Value Added terhadap return saham perusahaan otomotif yang tercatat di Bursa Efek Indonesia periode 20132016.

\section{TINJAUAN PUSTAKA}

\section{a. Return On Investment (ROI)}

Menurut Kasmir, S.E., M.M. (2016:201) Return on Investment (ROI) atau yang sering juga disebut dengan Return on Total Assets merupakan rasio yang menunjukkan hasil (return) atas jumlah aktiva yang digunakan dalam perusahaan. ROI 


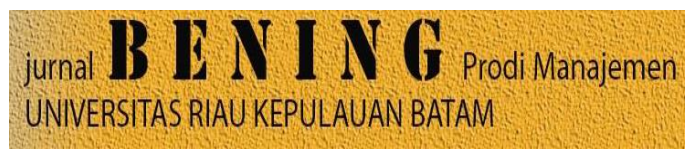

juga merupakan suatu ukuran tentang efektivitas manajemen dalam mengelola investasinya. Disamping itu hasil pengembalian investasi menunjukkan produktivitas dari seluruh dana perusahaan, baik modal pinjaman maupun modal sendiri. Semakin kecil (rendah) rasio ini, semakin kurang baik, demikian pula sebaliknya. Artinya rasio ini digunakan untuk mengukur efektifitas dari keseluruhan operasi perusahaan. Rumus untuk mencari Return On Invesment (ROI) dapat digunakan sebagai berikut :

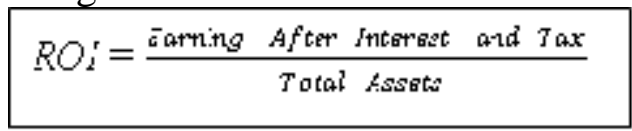

Terdapat 2 faktor yang dapat mempengaruhi ROI diantaranya :

1. Tingkat perputaran aktiva dalam kegiatan operasional perusahaan.

2. Profit margin, adalah besarnya keuntungan operasi yang dinyatakan dalam bentuk persentase dan jumlah penjualan bersih. Profit margin dapat mengukur tingkat keuntungan perusahaan dengan dihubungkan dengan penjualannya.

ROI sebagai bentuk teknik analisa rasio profitabilitas sangat penting dalam suatu perusahaan karena dengan mengetahui ROI dapat akan diketahui seberapa efisien perusahaan guna memanfaatkan aktiva untuk kegiatan operasional dan dapat memberikan informasi ukuran profitabilitas perusahaan. Menghitung ROI bagi perusahaan dianggap tidak kalah penting dengan margin keuntungan atas suatu produk ataupun jasa. Dengan mengetahui ROI suatu perusahaan akan mempunyai kepastian dan keyakinan usahanya dapat terus
Volume 5 No. 2 Tahun 2018

P-ISSN 2252-5262

E-ISSN 2614-499

berjalan dan berkembang karena margin keuntungan yang didapatkan dapat dijadikan sebagai modal untuk mengembangkan usaha perusahaan. resiko kegagalan akan dihadapi perusahaan apabila memperoleh margin keuntungan yang sedikit.

\section{b. Earning Per Share (EPS)}

Earning per share (EPS)

menurut Kasmir (2016:207)

merupakan rasio laba per lembar saham atau disebut juga rasio nilai buku, merupakan rasio untuk mengukur keberhasilan manajemen dalam mencapai keuntungan per lembar saham. Tandelilin (2001:241) mendefinisikan Earning Per Share (EPS) sebagai perbandingan antara jumlah laba (dalam hal ini laba bersih yang siap dibagikan bagi pemegang saham) dengan jumlah saham yang beredar.

Darmaji dan Fakhruddin (2006: 195) mendefinisikan Laba Per Saham sebagai rasio yang menunjukkan bagian laba untuk setiap saham. Earning Per Share menggambarkan profitabilitas perusahaan yang tergambar pada setiap lembar saham. Semakin tinggi nilai EPS tentu saja menyebabkan semakin besar laba dan kemungkinan peningkatan jumlah dividen yang diterima pemegang saham. Hal ini akan menarik perhatian investor sehingga banyak investor membeli saham perusahaan tersebut yang akan berpengaruh terhadap meningkatnya harga saham dan return saham yang akan meningkat pula.

Faktor-faktor penyebab kenaikan dan penurunan Earnings Per Share (EPS) adalah: 
a. Laba bersih naik dan jumlah lembar saham biasa yang beredar tetap.

b. Laba bersih tetap dan jumlah lembar saham biasa yang beredar turun.

c. Laba bersih naik dan jumlah lembar saham biasa yang beredar turun.

d. Persentase kenaikan laba bersih lebih besar daripada persentase kenaikan jumlah lembar saham biasa yang beredar.

e. Persentase penurunan jumlah lembar saham biasa yang beredar lebih besar daripada persentase penurunan laba bersih.

Jadi bagi suatu perusahaan, nilai laba per saham akan meningkat apabila persentase kenaikan laba bersihnya lebih besar daripada persentase kenaikan jumlah lembar saham biasa yang beredar, begitu pula sebaliknya.

Rumus untuk mencari laba per lembar saham (EPS) yaitu :

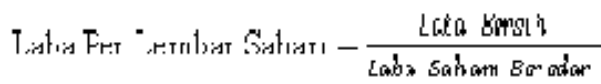

Pada penelitian ini penulis menggunakan rumus EPS dari Brigham dan Houston (2006: 19) karena pada laporan keuangan telah diketahui laba bersih dengan jumlah saham beredar yang dimiliki oleh setiap perusahaan pada setiap tahunnya, sehingga memudahkan peneliti untuk menghitung EPS. Pada penelitian sebelumnya juga banyak peneliti yang menggunakan rumus tersebut.

\section{c. Economic Value Added (EVA)} Brigham (2010) menyatakan bahwa Economic Value Added (EVA) adalah cara untuk mengukur profitabilitas operasi yang sesungguhnya. Biaya modal hutang (beban bunga) dikurangkan ketika menghitung laba bersih tetapi biaya ini tidak dikurangkan pada saat menghitung biaya modal ekuitas. Oleh karena itu, secara ekonomis, laba bersih ditetapkan terlalu tinggi dibandingkan laba yang sesungguhnya. Jadi, EVA menyelesaikan masalah akuntansi konvensional. Economic Value Added adalah ukuran keberhasilan manajemen perusahaan dalam meningkatkan nilai tambah (value added) bagi perusahaan. Asumsinya adalah bahwa jika kinerja manajemen baik/ efektif (dilihat dari besarnya nilai tambah yang diberikan), maka akan tercermin pada peningkatan harga saham perusahaan. Economic Value Added (EVA) merupakan keuntungan operasional setelah pajak, dikurangi biaya modal yang digunakan untuk menilai kinerja perusahaan dengan memperhatikan secara adil harapan-harapan para pemegang saham dan kreditur.

Metode Economic Value Added (EVA) sebagai Alat Ukur Kinerja Perusahaan. Konsep Economic Value Added (EVA) ini tidaklah dimaksudkan untuk mengganti laporan rugi laba yang telah ada. Namun pendekatan ini hanyalah alat analisis yang digunakan sebagai tambahan informasi keuangan yang sangat berguna bagi pihak kreditur dan penyedian dana dalam menentuakan hubungannya dengan perusahaan. Bagi eksekutif hasil pengukuran kinerja dengan metode Economic Value Added (EVA) seringkali digunakan untuk pengendalian serta sebagai alat yang 
sangat berguna didalam pengambilan keputusan - keputusan strategis.

Analisis Economic Value

Added (EVA) ini mencoba melihat dari segi ekonomis dalam pengukuran kinerja perusahaan dengan adil atas dasar konsep kepuasan stakeholder (seluruh anggota perusahaan), bentuknya adalah dengan mempertimbangkan harapan - harapan karyawan, pelanggan, dan pemberi modal (investor/pemegang saham). Derajat keadilannya adalah ditunjukkan oleh biaya modal rata rata tertimbang dan berpedoman terhadap nilai pasar.

EVA adalah sisa laba (residual income, excess earning) setelah penyedia modal memberikan kompensasi sesuai tingkat pengembalian (rate of return) yang dibutuhkan atau setelah semua biaya kapital yang digunakan untuk menghasilkan laba. Yang dimaksud dengan laba disini adalah Net Operating Profit After Tax (NOPAT) yaitu laba operasi bersih sesudah pajak. Sedangkan biaya kapital adalah biaya bunga pinjaman dari biaya ekuitas yang digunakan untuk menghasilkan NOPAT yang dihitung secara rata-rata tertimbang (Weighted Average Cost of Capital = WACC). EVA yang positif menunjukkan bahwa perusahaan berhasil menciptakan nilai (create value) bagi pemilik modal, konsisten dengan tujuan memaksimumkan nilai perusahaan. Sebaliknya EVA yang negatif menandakan nilai perusahaan berkurang sebagai akibat tingkat pengembalian yang dituntut investor. Manfaat dari penerapan EVA antara lain : a. Dapat digunakan sebagai penilai kinerja perusahaan yang berfokus pada penciptaan nilai (value creation).

b. Dapat meningkatkan kesadaran manajer bahwa tugas mereka adalah untuk memaksimumkan nilai perusahaan serta nilai pemegang saham.

c. Dapat membuat para manajer berfikir dan juga bertindak seperti halnya pemegang saham yaitu memilih investasi yang memaksimumkan tingkat pengembalian dan meminimumkan tingkat biaya modal sehingga nilai perusahaan dapat dimaksimumkan.

d. EVA membuat para manajer agar memfokuskan perhatian pada kegiatan yang menciptakan nilai dan memungkinkan mereka untuk mengevaluasi kinerja berdasarkan kriteria maksimum nilai perusahaan.

e. EVA sebagai motivator perusahaan untuk lebih memperhatikan kebijaksanaan struktur modalnya.

f. EVA dapat digunakan sebagai alat untuk mengidentifikasi proyek atau kegiatan yang memberikan pengembalian yang lebih tinggi dari pada biaya modal.

\section{d. Return Saham}

Menurut Brigham dan Houston (2006:215), return atau tingkat pengembalian adalah selisih antara jumlah yang diterima dan jumlah yang diinvestasikan, dibagi dengan jumlah yang diinvestasikan. Menurut Jogiyanto (2009:199), return saham dapat dibagi menjadi dua yaitu: Return realisasian (merupakan return yang telah terjadi yang dihitung berdasarkan data historis) dan Return 
ekspektasian (return yang diharapkan akan diperoleh oleh investor dimasa mendatang). Menurut Tandelilin (2001:48), return saham terdiri dari dua komponen, yaitu: Capital gain (loss) yaitu kenaikan (penurunan) harga suatu saham yang bisa memberikan keuntungan (kerugian) bagi investor dan Yield merupakan komponen return yang mencerminkan aliran kas atau pendapatan yang diperoleh secara periodik dari suatu investasi saham.Secara sistematis, perhitungan return saham adalah sebagai berikut:

Return Saham $=\frac{P 1-P 0}{P 0}$

$P_{t-1}$ atau $P_{0}=$ price, yaitu harga untuk waktu yang sebelumnya.

Karena pada laporan keuangan telah diketahui harga penutupan pada perusahaan setiap tahunnya dan karena tidak semua perusahaan membagikan dividen secara periodik sehingga pada penelitian ini penulis menggunakan rumus return saham yang di ambil dari Brigham dan Houston (2006:410) untuk memudahkan peneliti dalam menghitung return saham tersebut. Pada penelitian sebelumnya juga banyak peneliti yang menggunakan rumus tersebut. Menurut Samsul (2006:200), factor-faktor yang mempengaruhi return saham terdiri atas faktor makro dan faktor mikro.

\section{PENELITIAN TERDAHULU}

Penelitian sejenis telah dilakukan oleh Putu Vito Veda Janitra dan I Ketut Wijaya Kesuma (2015) yaitu Pengaruh Return On Investment (ROI), Earning Per Share (EPS) dan
Economic Value Added (EVA) terhadap Return Saham. Penelitian ini membuktikan bahwa variabel EPS dan ROI secara signifikan berpengaruh positif terhadap Return Saham perusahaan otomotif di BEI, sedangkan EVA tidak memiliki pengaruh yang signifikan terhadap return Saham di BEI .

Yuda Ditio Rahmadi (2013) melakukan penelitian tentang pengaruh Earning Per Share, Arus Kas Operasi, Economic Value Added, dan Market Value Added Terhadap Return Saham. Hasil penelitian ini menemukan bahwa Earning Per Share dan Economic Value Added tidak berpengaruh terhadap return saham, sedangkan arus kas operasi berpengaruh signifikan positif terhadap return saham dan Market Value Added berpengaruh positif namun tidak signifikan terhadap return saham.

Kennedy, Ruhul Fitrios, dan Mela Fajarini (2009) melakukan penelitian tentang pengaruh Return On Investment, Arus Kas Operasi dan Economic Value Added Terhadap Rate Of Return Saham. Hasil penelitian ini menemukan bahwa Return On Investment tidak berpengaruh signifikan terhadap return saham, sedangkan Arus Kas Operasi dan Economic Value Added berpengaruh signifikan terhadap return saham.

Pada penelitian Risdiyanto (2016) tentang pengaruh ROI, EPS dan PER terhadap Return Saham. Hasil penelitian ini menemukan bahwa PER berpengaruh signifikan terhadap return saham, sedangkan ROI dan EPS tidak berpengaruh terhadap return saham.

Agus Harjito dan Rangga Aryayoga (2009) menganalisis 


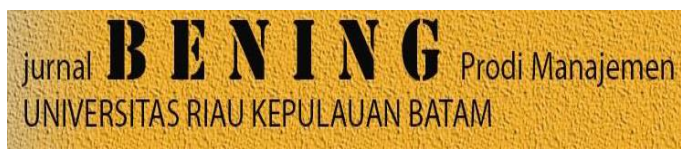

pengaruh kinerja keuangan dan return saham di Bursa Efek Indonesia. Sampel perusahaan yang digunakan adalah sebanyak 30 perusahaan manufaktur yang go public dan tercatat sebagai emiten sejak tahun 2004 sampai 2007 secara terus menerus. Teknik analisa yang digunakan penelitian ini adalah regresi linier berganda. Berdasarkan uji-t dapat diketahui bahwa ROA dan ROE mempunyai pengaruh negatif dan tidak signifikan, EVA mempunyai pengaruh negatif dan tidak signifikan, sedangkan NPM mempunyai pengaruh positif dan signifikan terhadap return saham perusahaan.

Geterida Pinangkaan (2012) melakukan penelitian yang berjudul pengaruh Return On Invesment (ROI) dan Economic Value Added (EVA) terhadap return saham studi kasus pada perusahaan semen, PT.XYZ yang telah go public dan memperdagangkan sahamnya di BEI tahun 2005-2009. Hasil penelitian ini bahwa ROI dan EVA secara bersama-sama mempunyai hubungan yang cukup kuat terhadap return saham PT.XYZ. Tapi secara parsial ROI dan EVA tidak berpengaruh signifikan terhadap return saham. Vera Anis dan Untung Sriwidodo (2012) dengan penelitiannya yang berjudul analisis faktor-faktor yang mempengaruhi return saham investor pada perusahaan manufaktur di Bursa Efek Indonesia. Hasilnya bahwa Return On Investment (ROI), Return On Equity (ROE) dan Earning Per Share (EPS) tidak ada pengaruh yang signifikan terhadap return saham dan variabel Economic Value Added (EVA) ada pengaruh yang
Volume 5 No. 2 Tahun 2018

P-ISSN 2252-5262

E-ISSN 2614-499

signifikan dengan saham. Secara bersama-sama ROI, ROE, EVA dan EPS mempunyai pengaruh yang signifikan terhadap return saham.

$$
\text { Yunita Anggraini }
$$

dengan penelitiannya yang berjudul pengaruh Return On Investment (ROI), Return On Equity (ROE), Earning Per Share (EPS), Economic Value Added (EVA) terhadap return saham pada perusahaan manufaktur di Bursa Efek Indonesia. Hasilnya bahwa Hasil penelitian menunjukkan bahwa secara parsial variabel Return On Invesment (ROI) dan Earning Per Share (EPS) berpengaruh signifikan terhadap return saham. Sedangkan variabel Return On Equity (ROE) dan Economic value Added (EVA) berpengaruh tidak signifikan terhadap return saham. Tetapi secara simultan variabel ROI, ROE, EPS, dan EVA berpengaruh signifikan terhadap return saham.

$$
\text { Latifah Ratnasari (2016) }
$$

dengan judul penelitiannya pengaruh Net Profit Margin (NPM), Return On Equity (ROE), Earning Per Share (EPS) terhadap return saham pada perusahaan farmasi di Bursa Efek Indonesia. Pengujian asumsi multikolinearias menunjukkan tidak terjadi. Pengujian asumsheteroskedastisitas menunjukkan tidak terjadi heteroskedastisitas. Uji t net profit margin (NPM) berpengaruh positif terhadap return saham karena signifikansinya $0.010 \quad(<0.050)$. Uji t return on equity (ROE) berpengaruh negaif terhadap return saham karena signifikansinya 0.787 (>0.05). Uji t Earning Per Share (EPS) berpengaruh positif terhadap return saham karena signifikansinya $0.029(<0.050)$. 


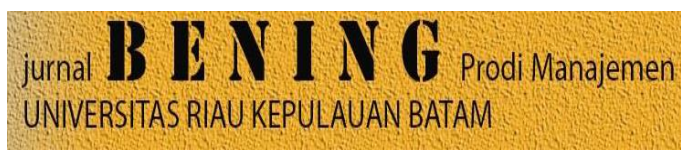

Selviani (2015) dengan penelitiannya yang berjudul pengaruh laba bersih, arus kas dan return on investment terhadap return saham pada perusahaan maufaktur di BEI. Hasil dalam penelitian ini menunjukkan secara parsial variabel Laba Bersih berpengaruh signifikan terhadap Return Saham, dan Arus Kas Operasi berpengaruh signifikan terhadap Return Saham, sedangkan variabel Arus Kas Investasi tidak berpengaruh signifikan terhadap Return Saham, Arus Kas Pendanaan tidak berpengaruh signifikan terhadap Return Saham, dan Return On Investment tidak berpengaruh signifikan terhadap Return Saham. Hasil penelitian menunjukkan secara simultan variabel Laba Bersih, Arus Kas Operasi, Arus Kas Investasi, Arus Kas Pendanaan, dan Return On Investment berpengaruh signifikan terhadap Return Saham pada perusahaan Manufaktur yang terdaftar di Bursa Efek Indonesia periode 20112014.

\section{KERANGKA PEMIKIRAN}

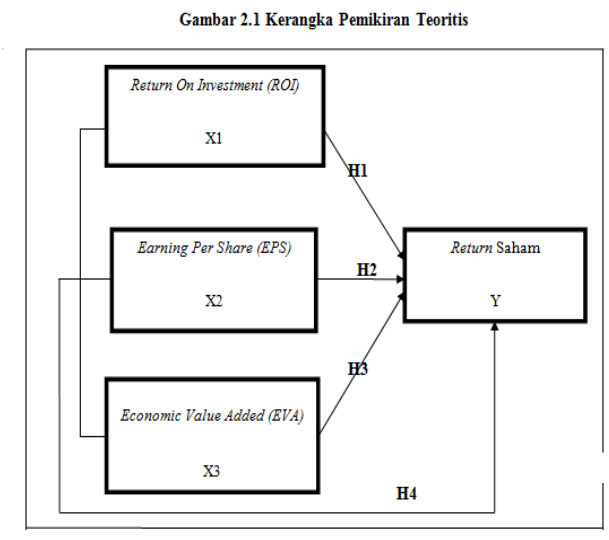

\section{HIPOTESIS PENELITIAN}

$\mathrm{H}_{\mathrm{a} 1}$ : Return On Investment (ROI) berpengaruh terhadap return
Volume 5 No. 2 Tahun 2018

P-ISSN 2252-5262

E-ISSN 2614-499

saham perusahaan Otomotif yang tercatat di Bursa Efek Indonesia periode 2013-2016.

$\mathrm{H}_{\mathrm{O} 1}$ : Return On Investment (ROI) tidak berpengaruh terhadap return saham perusahaan otomotif yang tercatat di Bursa Efek Indonesia periode 20132016.

$\mathrm{H}_{\mathrm{a} 2}$ : Earning Per Share (EPS) berpengaruh terhadap return saham perusahaan otomotif yang tercatat di Bursa Efek Indonesia periode 2013-2016.

$\mathrm{H}_{\mathrm{O} 2}$ : Earning Per Share (EPS) tidak berpengaruh terhadap return saham perusahaan otomotif yang tercatat di Bursa Efek Indonesia periode 2013-2016.

$\mathrm{H}_{\mathrm{a} 3}$ : Economic Value Added (EVA) berpengaruh terhadap return saham perusahaan otomotif yang tercatat di Bursa Efek Indonesia periode 2013-2016.

$\mathrm{H}_{\mathrm{o}}$ : Economic Value Added (EVA) tidak berpengaruh terhadap return saham perusahaan otomotif yang tercatat di Bursa Efek Indonesia periode 20132016.

$\mathrm{H}_{\mathrm{a} 4}$ : Return On Investment (ROI), Earning Per Share (EPS), Economic Value Added (EVA) secara simultan berpengaruh terhadap return saham perusahaan otomotif yang tercatat di Bursa Efek Indonesia periode 2013-2016.

$\mathrm{H}_{\mathrm{O} 4}$ : Return On Investment (ROI), Earning Per Share (EPS), Economic Value Added (EVA) secara simultan tidak berpengaruh terhadap return saham perusahaan otomotif 


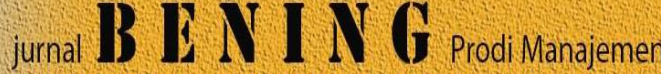

UNIVERSITAS RIAU KEPULAUAN BATAM

yang tercatat di Bursa Efek Indonesia periode 2013-2016.

\section{METODE PENELITIAN}

\section{Lokasi dan Objek Penelitian}

Penelitian ini mengambil tempat di Bursa Efek Indonesia. Objek pada penelitian ini dilakukan di kantor IDX yang beralamat di komplek Mahkota Raya Blok A No.11 Jl. Fisabililah Batam Center 29456 Batam- Kepulauan Riau, pada masingmasing perusahaan otomotif yag terdaftar di Bursa Efek Indonesia.

\section{Populasi dan Sampel}

Populasi yang digunakan dalam penelitian ini adalah 13 perusahaan otomotif. Dan sampel yang digunakan adalah 11 perusahaan otomotif yang terdaftar di Bursa Efek Indonesia periode 2013-2016.

\section{Metode Pengumpulan Data}

Data yang diambil dalam penelitian ini adalah data sekunder, yaitu data yang diperoleh secara tidak langsung melalui media perantara (Diperoleh dan dicatat oleh pihak lain) dengan kata lain pengumpulan data diperoleh dari website Bursa Efek Indonesia dan beberapa literature yang berkaitan dengan masalah yang sedang diteliti.

\section{Variabel Penelitian}

1. Variabel independen adalah variabel yang mempengaruhi atau yang menjadi sebab perubahan variabel dependen. Variabel independen dalam penelitian ini yaitu Return On Investment (ROI) (X1), Earning Per Share (EPS) (X2), dan Economic Value Added (EVA) (X3).

2. Variabel dependen merupakan variabel yang dipengaruhi atau menjadi akibat karena adanya variabel independen. Variabel
Volume 5 No. 2 Tahun 2018

P-ISSN 2252-5262

E-ISSN 2614-499

dependen dalam penelitian ini yaitu Return Saham.

\section{Metode Analisis Data}

Teknik analisis data yang digunakan dalam penelitian ini adalah analisis statistik deskriptif, analisis regresi data panel untuk menentukan pengaruh dari variabel independen terhadap variabel dependen menggunakan regresi berganda dengan uji asumsi klasik, untuk mengetahui tingkat signifikan dari setiap koefisien regresi variabel independen terhadap variabel dependen maka akan digunakan uji statistik.

\section{Teknik Analisa Data \\ Uji Asumsi Klasik \\ Uji Normalitas}

Uji normalitas bertujuan untuk menguji apakah dalam model regresi, baik variabel maupun dependen, telah berdistribusi secara normal. Model regresi yang baik adalah model regresi yang memiliki distribusi data normal atau mendekati normal. Untuk mengetahui normal atau tidaknya distribusi data dapat dideteksi dengan melihat hasil Uji Kolmogorov Smirnov.

Uji Kolmogorov Smirnov merupakan pengujian normalitas yang banyak dipakai, terutama setelah adanya banyak program statistik yang beredar. Kelebihan dari uji ini adalah sederhana dan tidak menimbulkan perbedaan persepsi diantara satu pengamat dan pengamat lain, yang sering terjadi pada uji normalitas dengan menggunakan grafik. Konsep dasar dari uji normalitas Kolmogorov Smirnov adalah dengan membandingkan distribusi data (yang akan diuji normalitasnya) dengan 


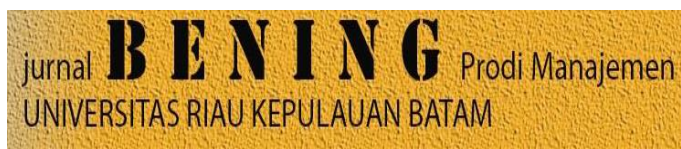

distribusi normal baku. Distribusi normal baku adalah data yang telah ditransformasikan kedalam bentuk Zscore dan diasumsikan normal. Seperti pada uji beda biasa, jika signifikansi dibawah 0,05 berarti terdapat perbedaan yang signifikan dan jika signifikansi diatas 0,05 maka tidak terjadi perbedaan yang signifikan. Penerapan pada uji Kolmogorov Smirnov adalah bahwa jika signifikansi dibawah 0,05 berarti data yang akan diuji mempunyai perbedaan yang signifikan dengan data normal baku, berarti data tersebut tidak normal. $\mathrm{P}<0,05$ berarti distribusi data tidak normal, $\mathrm{P} \geq 0,05$ berarti distribusi data normal.

\section{Uji Multikolinienitas}

Uji multikolinieritas berarti ada hubungan diantara beberapa variabel atau semua variabel independen dalam model regresi. Jika dalam model tersebut memiliki kesalahan standar yang besar sehingga koefesien tidak dapat ditaksir dengan ketepatan tinggi (Ghozali,2013:91). Dasar pengambilan keputusan dengan tolerance value atau variance inflation factor (VIF) dapat disimpulkan jika nilai tolerance > 0,1 dan nilai VIF < 10, maka dapat disimpulkan bahwa tidak ada multikolinearitas antar variabel independen dalam model regresi, dan jika nilai tolerance $<0,1$ dan nilai VIF >10, maka dapat disimpulkan bahwa ada multikolinearitas antar variabel independen dalam model regresi.

\section{Uji Autokorelasi}

Uji autokorelasi bertujuan untuk menguji apakah sebuah model regresi linier terdapat korelasi antara kesalahan penggangu pada periode $\mathrm{t}$
Volume 5 No. 2 Tahun 2018

P-ISSN 2252-5262

E-ISSN 2614-499

dengan periode $t-1$ sebelumnya (Ghozali, 2013:95). Untuk mengetahui apakah adanya autokorelasi di antara variabel- variabel indepanden, dapat dilihat dari angka D-W (durbinwatson). Dasar pengambilan keputusan adalah bila nilai $\mathrm{D}-\mathrm{W}$ terletak antara -2 sampai dengan 2, maka koefesien autokorelasi sama dengan nol, berarti tidak ada autokorelasi. Bila nilai D-W lebih rendah -2 , maka koefesien autokorelasi lebih besar dari pada nol, berarti ada autokorelasi positif. Bila nilai D-W lebih besar dari 2, maka koefesien autokorelasi lebih kecil dari pada nol, berarti ada autokorelasi negatif.

\section{Uji Heteroskesdasitas}

Menurut Ghozali (2013:105), uji heteroskedasitas bertujuan untuk menguji apakah dalam model regresi terjadi ketidaksamaan variance dari residual satu pengamatan ke pengamatan lain. Untuk mendeteksi ada tidaknya heteroskedastisitas yaitu dengan melihat grafik scatterplots dengan dasar pengambilan keputusan apabila ada pola tertentu, seperti titiktitik yang ada membentuk pola tertentu yang teratur (bergelombang, melebar, kemudian menyempit), maka mengindikasikan telah terjadi heteroskedastisitas. Jika ada pola yang jelas, serta titik-titik menyebar di atas dan di bawah angka 0 dan pada sumbu Y, maka tidak terjadi heteroskedastisitas. Pada penelitia ini uji statistic yang digunakan adalah uji Glejser, dasar pengambilan keputusan uji heterokedastisitas melalui uji Glejser adalah :

a. Apabila sig. 2-tailed $<\alpha=0,05$, maka telah terjadi heterokedastisitas. 
b. Apabila sig. 2-tailed $>\alpha=0,05$, maka tidak terjadi heterokedastisitas.

Uji heterokedastisitas grafik Scatterplot antara nilai prediksi variable terikat, yaitu ZPRED (sumbu $X)$ dengan residualnya SRESID (sumbu Y). Apabila titik-titik menyebar secara acak dan tersebut baik diatas maupun dibawah angka 0 (nol) pada sumbu Y, maka tidak terjadi heterokedastisitas pada model regresi, sehingga layak dipakai untuk memprediksi variable terikat berdasarkan masukan variable bebas (Ghazali, 2013:139-141) di dalam ginting dkk 2016.

\section{Pengujian Hipotesis}

\section{Analisis Regresi Linier Berganda}

Analisis regresi berganda yang memperlihatkan hubungan atau pengaruh antara dua variabel atau lebih variabel independen (X) dengan variabel dependen (Y), pada penelitian ini analisis regresi berganda dapat dirumuskan sebagai berikut:

$\mathrm{Y}=\mathrm{a}+\mathrm{b}_{1}$ Roi $+\mathrm{b}_{2}$ Eps $+\mathrm{b}_{3}$ Eva $+\mathrm{e}$

\section{Keterangan :}

$\mathrm{Y}=$ Return Saham

$\mathrm{a}=$ Konstanta

$\mathrm{b} \quad=$ Koefisien regresi dari masingmasing variabel

Roi $=$ Return On Investment (ROI)

Eps = Earning Per Share (EPS)

Eva $=$ Economic Value Added $(\mathrm{EVA})$

$\mathrm{e} \quad=$ Unsur Eror

\section{Uji Statistik t}

Uji $\mathrm{t}$ digunakan untuk menguji signifikansi pengaruh Return On Investment, Earning Per Share dan Economic Value Added Perusahaan Otomotif di Bursa Efek Indonesia periode 20013 - 2016 secara parsial.
1) Perbandingan thitung dengan t tabel a. Jika $\mathrm{t}$ hitung $<\mathrm{t}$ tabel, maka HO diterima dan $\mathrm{H} 1$ ditolak.

b. Jika $\mathrm{t}$ hitung > t tabel, maka $\mathrm{H} 0$ ditolak dan $\mathrm{H} 1$ diterima.

2) Perbandingan nilai signifikansi dengan taraf nyata

a. Jika nilai signifikansi > taraf nyata $(0,05)$, maka H0 diterima dan $\mathrm{H} 1$ ditolak.

b. Jika nilai signifikansi < taraf nyata $(0,05)$, maka H0 ditolak dan H1 diterima.

\section{Uji Statistik F}

Uji $\mathrm{F}$ digunakan untuk menguji signfikansi pengaruh Return On Investment, Earning Per Share dan Economic Value Added Perusahaan Otomotif di Bursa Efek Indonesia periode 20013 - 2016 secara simultan :

1) Perbandingan $f$ hitung dengan $f$ tabel

a. Jika $\mathrm{F}$ hitung $\leq \mathrm{f}$ tabel, maka $\mathrm{H} 0$ diterima dan $\mathrm{H} 1$ ditolak.

b. Jika $\mathrm{F}$ hitung $>\mathrm{f}$ tabel, maka H0 ditolak dan $\mathrm{H} 1$ diterima.

2) Perbandingan nilai signifikansi dengan taraf nyata

a. Jika nilai signifikansi $\geq$ taraf nyata $(0,05)$, maka H0 diterima dan $\mathrm{H} 1$ ditolak.

b. Jika nilai signifikansi < taraf nyata $(0,05)$, maka H0 ditolak dan H1 diterima.

\section{Koefisien Determinasi (R2)}

Analisis determinasi digunakan untuk mengetahui persentase hubungan pengaruh variabel independen secara bersama-sama terhadap variabel dependen. Koefisien determinasi menunjukkan seberapa besar persentase variabel independen yang digunakan dalam model mampu 
$\begin{aligned} & \text { jurnal } \\ & \text { UNIVERSITAS RIAU KEPULAUAN BATAM }\end{aligned}$
UN I I Prodi Manajemen

menjelaskan variasi variabel dependen. Nilai R2 sama dengan 0, maka tidak ada sedikitpun pengaruh persentase variabel independen y dalam model mampu menjelaskan variasi variabel dependen. Sebaliknya, R2sama dengan 1, menandakan variabel-variabel independen memberikan hampir semua informasi yang dibutuhkan oleh variabel dependen.

\section{HASIL PENELITIAN DAN PEMBAHASAN \\ Uji Asumsi Klasik Uji Normalitas}

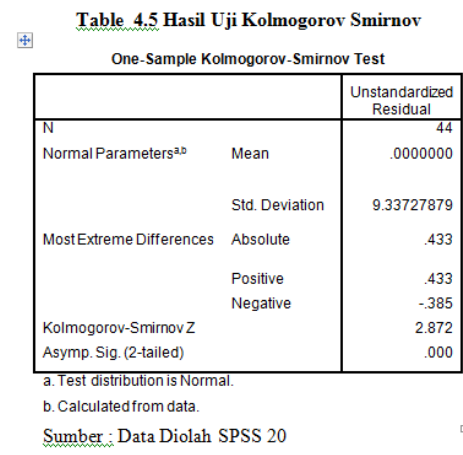

Berdasarkan output diatas, diketahui bahwa nilai signifikansi sebesar 0,000 lebih kecil dari $<0,05$ sehingga dapat disimpulkan bahwa data yang diuji berdistribusi tidak normal.

\section{Uji Multikolinearitas}

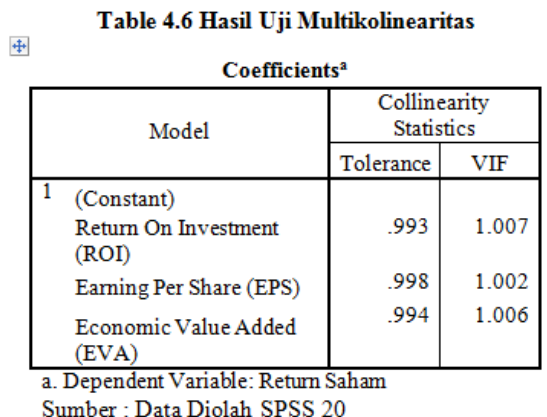

Volume 5 No. 2 Tahun 2018

P-ISSN 2252-5262

E-ISSN 2614-499

Nilai Tolerance variable Return On Investment (ROI) sebesar 0.993, Earning Per Share (EPS) sebesar 0.998, Economic Value Added (EVA) sebesar $0.994<10$. Sedangkan nilai VIF variable Return On Investment (ROI) sebesar 1.007, Earning Per Share (EPS) sebesar 1.002, Economic Value Added (EVA) sebesar $1.006<10$. Sehingga disimpulkan maka tidak terjadi multikolinearitas antara variable independen dalam model regresi linier.

\section{Uji Heterokedastisitas}

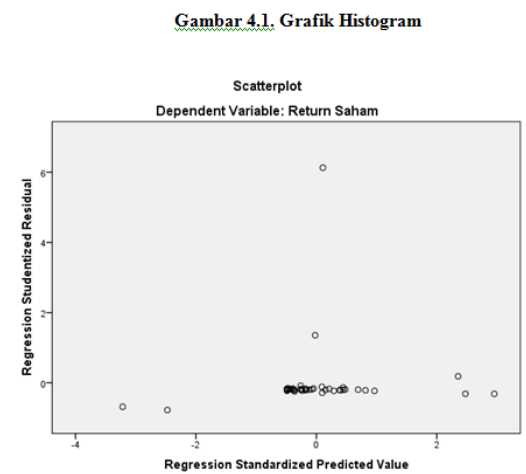

Sumber: Data Diolah SPSS 20

$\begin{array}{ccc}\text { Berdasarkan output diatas, } \\ \text { dengan } & \text { memperhatikan } & \text { grafik }\end{array}$ scatterplot yang tampak pada gambar 4.1 terlihat bahwa titik-titik menyebar secara acak dan tersebar merata baik diatas sumbu $\mathrm{X}$ ataupun sumbu $\mathrm{Y}$, serta titik-titik berkumpul disuatu tempat dan tidak membentuk suatu pola tertentu. hal ini dapat disimpulkan bahwa tidak mengalami masalah heterokedastisitas pada model regresi ini, karena antara variable independen tidak saling mempengaruhi.

\section{Uji Autokorelasi}




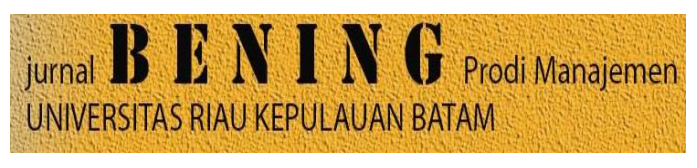

Table 4.7 Hasil Uji Autokorelasi

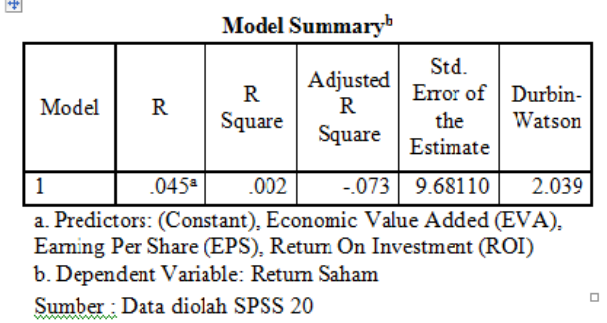

Pada table uji autokorelasi diatas, terlihat angka D-W sebesar 2.039. Angka D-W tersebut lebih besar dari 2, maka koefisien autokorelasi lebih kecil daripada nol, berarti ada autokorelasi negative.

\section{PENGUJIAN HIPOTESIS}

\section{Regresi Linier Berganda}

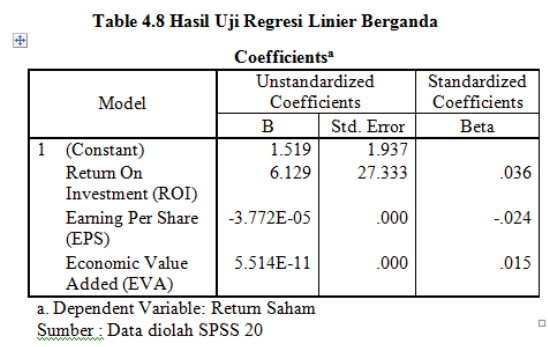

Hubungan antara Return On Investment (ROI), Earning Per Share (EPS) dan Economic Value Added (EVA) terhadap Return Saham Perusahaan Otomotif menghasilkan suatu persamaan sebagai berikut :

$\mathrm{Y}=\mathrm{a}+\mathrm{b} 1 \mathrm{x} 1+\mathrm{b} 2 \times 2+\mathrm{b} 3 \times 3$

$\mathrm{Y}=1.519+6.129 \mathrm{X} 1+(-3.772) \mathrm{X} 2+$ $5.514 \times 3$

Persamaan regresi diatas dapat dijelaskan sebagai berikut :

a. Berdasarkan persamaan di atas diperoleh konstanta sebesar 1.519. hal ini berarti bahwa dengan adanya Return On Investment (ROI), Earning Per Share (EPS) dan Economic Value Added (EVA) nilai konstan Return Saham sebesar 1.519.
Volume 5 No. 2 Tahun 2018

P-ISSN 2252-5262

E-ISSN 2614-499

b. Koefisien regresi Return On Investment (ROI) sebesar 6.129 artinya bahwa peningkatan $1 \%$ variable Return On Investment (ROI) dengan asumsi variable bebas lain konstan akan menyebabkan penurunan return saham sebesar 6.129, demikian sebaliknya jika penurunan Return On Investment (ROI) $1 \%$ akan menyebabkan peningkatan return saham sebesar 6.129.

c. Koefisien regresi variable Earning Per Share (EPS) sebesar -3.772 artinya bahwa peningkatan $1 \%$ variable Earning Per Share (EPS) dengan asumsi variable bebas lain konstan akan menyebabkan penurunan return saham sebesar -3.772, demikian sebaliknya jika penurunan Earning Per Share (EPS) $1 \%$ menyebabkan peningkatan return saham sebesar 3.772 .

d. Koefisien regresi Economic Value Added (EVA) sebesar 5.514 artinya bahwa peningkatan $1 \%$ variable Economic Value Added (EVA) dengan asumsi variable bebas lain konstan akan menyebabkan kenaikan return saham sebesar 5.514, demikian sebaliknya jika penurunan Economic Value Added (EVA) 1\% akan menyebabkan penurunan return saham sebesar 5.514.

\section{Uji Statistik t}

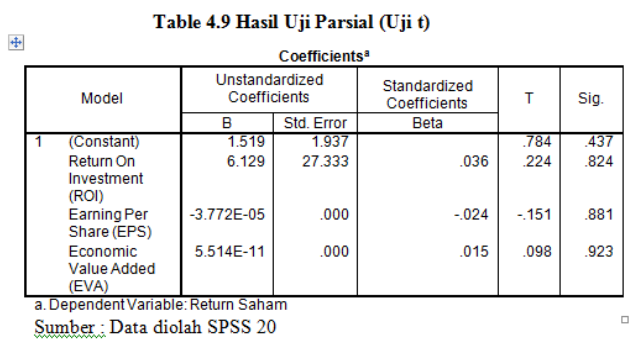

Dari table diatas dapat dilihat yaitu : 
a. Return On Investment (ROI) mempunyai sebesar 0.224 dengan signifikansi 0.824. Hal tersebut menunjukkan bahwa signifikansinya > 0,05 sehingga $\mathrm{H} 1$ tidak diterima, jadi dapat disimpulkan bahwa Return On Investment (ROI) tidak memiliki pengaruh yang signifikan terhadap return saham.

b. Earning Per Share (EPS) mempunyai sebesar -0.151 dengan signifikansi $0.881>0,05$ sehingga $\mathrm{H} 2$ tidak diterima, jadi dapat disimpulkan bahwa Earning Per Share (EPS) tidak memiliki pengaruh yang signifikan terhadap Return saham.

c. Economic Value Added (EVA) mempunyai sebesar 0.098 dengan signifikansi 0.923. Hal tersebut menunjukkan bahwa signifikansi > 0,05 sehingga $\mathrm{H} 3$ tidak diterima, jadi dapat disimpulkan bahwa Economic Value Added (EVA) tidak memiliki pengaruh yang signifikan terhadap Return saham.

\section{Uji Statistik f}

\begin{tabular}{|c|c|c|c|c|c|}
\hline Model & $\begin{array}{l}\text { Sum of } \\
\text { Squares }\end{array}$ & $\mathrm{Df}$ & $\begin{array}{c}\text { Mean } \\
\text { Square }\end{array}$ & F & Sig. \\
\hline 1 Regression & 7.738 & 3 & 2.579 & .028 & $.994^{\mathrm{b}}$ \\
\hline Residual & 3748.945 & 40 & 93.724 & & \\
\hline Total & 3756.683 & 43 & & & \\
\hline \multicolumn{6}{|c|}{ a. Dependent Variable: Return Saham } \\
\hline \multicolumn{6}{|c|}{$\begin{array}{l}\text { b. Predictors: (Constant), Economic Value Added (EVA), Earning Per Share } \\
\text { (EPS), Retum On Investment (ROI) }\end{array}$} \\
\hline
\end{tabular}

Berdasarkan hasil perhitungan uji ANOVA / Uji f pada table 4.10 diperoleh nilai $\mathrm{F}$ hitung sebesar 0.028 dengan tingkat signifikansi $0.994^{\mathrm{b}}$ lebih besar dari 0.05 (0.994>0.05) sehingga dapat disimpulkan Ho diterima dan $\mathrm{Ha}$ ditolak. Hal ini berarti Ha4 yaitu "Tidak ada pengaruh yang signifikan Return On Investment (ROI), Earning Per Share (EPS) dan Economic Value Added (EVA) secara simultan (bersama-sama) terhadap Return Saham pada Perusahaan Otomotif yang Terdaftar di Bursa Efek Indonesia" ditolak.

\section{Koefisien Determinasi}

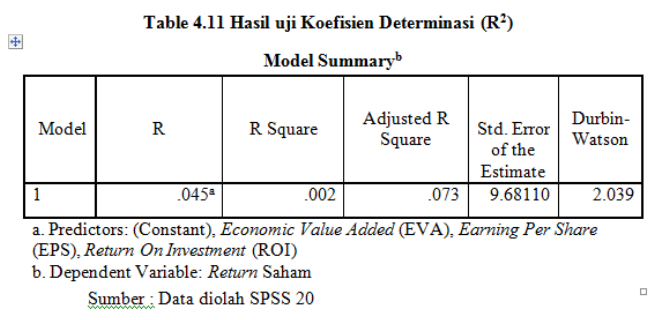

Dilihat dari table 4.11 diatas, dapat dilihat bahwa nilai Adjusted $\mathrm{R}^{2}$ sebesar 0.073 yang berarti sebesar 7,3 $\%$ variable dependen Return saham dan variable independen yaitu Return On Investment, Earning Per Share dan Economic Value Added dapat disimpulkan bahwa terjadi hubungan yang sangat rendah.

Hal ini didasarkan oleh pedoman untuk memberikan interpretasi koefisien korelasi sebagai berikut :

$0,00-0,199=$ sangat rendah

$0,20-0,399=$ rendah

$0,40-0,599=$ sedang

$0,60-0,799=$ kuat

$0,80-1,000=$ sangat kuat

Sugiyono, 2007).

Hasil analisis koefisien determinasi $\left(\mathrm{R}^{2}\right)$ menunjukkan bahwa prosentase sumbangan pengaruh variable independent terhadap variable dependent adalah sebesar 92,7 \%. Sedangkan sisanya sebesar 7,3\% dipengaruhi oleh variable lain yang tidak dimasukkan atau tidak dibahas dalam penelitian ini. 
jurnal $\$ 1 \cap I N$ I Prodi Manajemen

UNIVERSITAS RIAU KEPULAUAN BATAM

PEMBAHASAN

HASIL

PENELITIAN

Pengaruh Return On Investment (ROI) terhadap Return Saham

Hasil penelitian menunjukkan bahwa Return On Investment (ROI) tidak berpengaruh secara signifikan terhadap return saham. Hal ini disebabkan secara keseluruhan potensi peningkatan Return On Investment (ROI) akan mempengaruhi kenaikan Return Saham. Penelitian ini mendukung penelitian Kennedy, Fitrios, dan Fajarini (2009) yang menunjukkan bahwa Return On Investment (ROI) tidak memberikan pengaruh terhadap return saham. Penelitian ini tidak mendukung penelitian Janitra dan Kesuma (2015) yang membuktikan bahwa variable ROI berpengaruh positif terhadap return saham.

\section{Pengaruh Earning Per Share (EPS)} terhadap Return Saham

Dalam penelitian ini variable Earning Per Share (EPS) terus meningkat tidak akan mempengaruhi Return saham. Hal ini menunjukkan bahwa tidak terdapat pengaruh yang signifikan antara Earning Per Share (EPS) terhadap return saham. Penelitian ini mendukung penelitian Rahmadi (2013) yang menunjukkan bahwa Earning Per Share (EPS) tid ak berpengaruh signifikan terhadap return saham. Penelitian ini tidak mendukung penelitian Anggraini (2014) yang membuktikan bahwa variable EPS berpengaruh signifikan terhadap return saham.

Pengaruh Economic Value Added (EVA) terhadap Return Saham
Volume 5 No. 2 Tahun 2018

P-ISSN 2252-5262

E-ISSN 2614-499

Dalam penelitian ini variable Economic Value Added (EVA) apabila meningkat maka akan mempengaruhi naik turunnya Return saham. Hal ini ditunjukkan bahwa EVA tidak memiliki pengaruh yang signifikan terhadap return saham. Penelitian ini mendukung penelitian Janitra dan Kesuma (2015), menyatakan bahwa Economic Value Added (EVA) tidak berpengaruh signifikan terhadap return saham. Penelitian ini tidak mendukung penelitian Anis dan Sriwidodo (2012) yang membuktikan bahwa EVA ada pengaruh yang signifikan terhadap return saham.

Pengaruh Return On Investment (ROI), Earning Per Share (EPS), Economic Value Added (EVA) Secara Simultan terhadap Return Saham

Hasil penelitian ini menyatakan bahwa secara simultan variable Return On Investment (ROI), Earning Per Share (EPS) dan Economic Value Added (EVA) tidak berpengaruh terhadap return saham. Selain uji hasil simultan, terdapat pula hasil uji koefisien determinasi, dimana koefisien determinasi yang disesuaikan (Adjusted R2) menunjukkan angka $7.3 \%$. interpretasinya adalah variable return saham dipengaruhi oleh Return On Investment (ROI), Earning Per Share (EPS) dan Economic Value Added (EVA) sebesar $7.3 \%$ dan sisanya dipengaruhi oleh variable lain di luar penelitian ini. Hal ini terjadi karena return saham di suatu negara dipengaruhi oleh keadaan ekonomi 
makro negara tersebut. Oleh karena itu sebelum mengambil keputusan untuk menanamkan modalnya, seorang investor harus memperhatikan keadaan ekonomi makro seperti variablevariabel dalam penelitian ini.

\section{KESIMPULAN DAN SARAN Kesimpulan}

Berdasarkan hasil penelitian dari uji SPSS dan perhitungan variable penelitian laporan keuangan perusahaan yang diteliti, maka dapat diambil kesimpulan penelitian sebagai berikut :

1. Secara parsial variable Return On Investment (ROI) tidak berpengaruh secara signifikan terhadap return saham pada perusahaan otomotif yang terdaftar di Bursa Efek Indonesia Tahun 2013-2016. Return On Investment (ROI) mempunyai sebesar 0.224 dengan signifikansi 0.824 . Hal tersebut menunjukkan bahwa signifikansinya $>0.05$.

2. Secara parsial variable Earning Per Share (EPS) tidak berpengaruh secara signifikan terhadap return saham pada perusahaan otomotif yang terdaftar di Bursa Efek Indonesia Tahun 20132016. Earning Per Share (EPS) mempunyai sebesar -0.151 dengan signifikansi $0.881>0.05$.

3. Secara parsial variable Economic Value Added (EVA) tidak berpengaruh secara signifikan terhadap return saham pada perusahaan otomotif yang terdaftar di Bursa Efek Indonesia Tahun 2013-2016.

Economic Value Added (EVA) mempunyai sebesar 0.098 dengan signifikansi 0.923. Hal tersebut menunjukkan bahwa signifikansi > 0.05 .
4. Secara simultan variable Return On Investment (ROI), Earning Per Share (EPS) dan Economic Value Added (EVA) tidak berpengaruh secara signifikan terhadap return saham pada perusahaan otomotif yang terdaftar di Bursa Efek Indonesia Tahun 20132016. Berdasarkan hasil perhitungan uji annova / uji $\mathrm{f}$ diperoleh nilai $\mathrm{F}$ Hitung sebesar 0.028 dengan tingkat signifikan si $0.994 \mathrm{~b}$ lebih besar dari $0.05(0.994>0.05)$.

\section{Saran}

Adapun saran-saran yang dapat diberikan melalui hasil penelitian ini adalah sebagai berikut :

1. Saran untuk meningkatkan total asset pada peusahaan Otomotif, maka perusahaan harus menaikkan tingkat Return On Investment (ROI), Earning Per Share (EPS) dan Economic Value Added (EVA) pada periode tahun berikutnya agar banyak investor yang tertarik menginvestasikan dananya dalam bentuk saham.

2. Bagi peneliti berikutnya disarankan menambahkan periode penelitian yang lebih panjang serta variable independen lain selain Return On Investment (ROI), Earning Per Share (EPS) dan Ecoomic Value Added (EVA) karena berdasarkan penelitian ini nilai koefisiennya sebesar $7.3 \%$ sedangkan sisanya dipengaruhi variable atau factor-faktor lain di luar model penelitian. hal ini agar dapat menghasilkan penelitian yang bisa menambah dugaan atau hipotesis yang lain.

3. Bagi investor yang akan berinvestasi dalam bentuk saham di bursa efek Indonesia, peneliti menyarankan untuk mengamati di setiap naik dan turunnya nilai Return On Investment (ROI), 


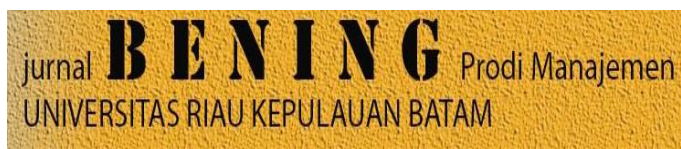

Earning Per Share(EPS) dan Economic Value Added (EVA) dalam pengembalian return saham. Sehingga investor dapat menentukan yang tepat dalam membuat keputusan untuk menginvestasikan dana, salah satunya pada perusahaan otomotif.

4. Bagi Emiten

Hasil penelitian ini menyatakan bahwa Return On Investment (ROI), Earning Per Share (EPS) dan Economic Value Added (EVA) tidak berpengaruh secara signifikan terhadap return saham, sehingga perusahaan emiten disarankan menginformasikan nilai Return On Investment (ROI), Earning Per Share (EPS) dan Economic Value Added (EVA) kepada investor maupun calon investor agar dapat dijadikan pertimbangan dalam pengambilan keputusan.

\section{DAFTAR PUSTAKA}

Brigham, Eugene $\mathrm{F}$ dan Houston. 2006. Fundamental of Financial Management : Dasar-dasar Manajemen Keuangan. Edisi 10. Jakarta : Salemba Empat.

Darmadji dan Fakhruddin. 2012. Pasar modal di Indonesia. Salemba Empat, Jakarta.

Ghozali,I. 2013. Aplikasi Analisis Multivariate dengan Program SPSS. Cetakan Keempat. Badan Penerbit Universitas Diponegoro. Semarang.

Harahap Sofyan Syafitri. 2011. Analisis Kritis Atas Laporan Keuangan. Jakarta: Rajawali Press.

Hartono, Jogiyanto. 2010. Teori Portofolio dan Analisis
Volume 5 No. 2 Tahun 2018

P-ISSN 2252-5262

E-ISSN 2614-499

Investasi. Edisi Ketujuh. Yogyakarta : BPFE.

Janitra, Putu Vito Veda ; Kesuma, I Ketut Wijaya. 2015. Pengaruh EPS, ROI, dan EVA terhadap Return Saham (Studi Kasus Perusahaan Otomotif di BEI ). Jurnal Manajemen Unud, Vol. 4, No. 7: Hal. 1831-1844.

Jogiyanto H.M. 2013. Teori Portofolio dan Analisa investasi. Edisi Ketujuh.Keempat.ekonisia. Yogyakarta.

Kasmir, 2008. Analisis Laporan Keuangan. Cetakan Kelima. Jakarta : PT. Raja Grafindo Persada.

Kasmir, S.E., M.M. 2016. Analisis Laporan Keuangan. Edisi Pertama. Cetakan kesembilan. Rajawali Pers. Jakarta.

Kennedy; Fitrios, Ruhul; Fajarini, Mela. 2009. Pengaruh Return On Investment, Arus Kas Operasi dan Economic Value Added Terhadap Rate Of Return Saham (Studi Kasus Perusahaan Mnufaktur Yang Terdaftar Di BEJ). Jurnal Ekonomi. Vol. 17, No. 2.

Keown, Arthur., J, et all. 2011. Dasar - Dasar Manajemen Keuangan. Diterjemahkan oleh Chaerul D. Djakman. Edisi Ke 7, Buku 1. Jakarta : Salemba Empat

Mardiyanto, Handoyo. 2009. Intisari Manajemen Keuangan. Jakarta : PT Grasindo.

Munawir. 2000. Analisa Laporan Keuangan. Edisi 4. Liberty, Yogyakarta.

Pinangkaan, Geterida. 2012. Pengaruh Return On Invesment (ROI) dan Economic Value Aded 


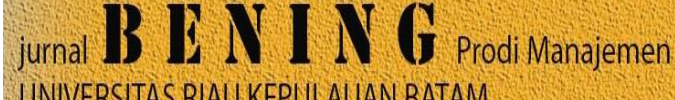

UNIVERSITAS RIAU KEPULAUAN BATAM

(EVA) Terhadap Return Saham

Perusahaan. Jurnal Ilmiah STIE MDP. Vol.1, Maret, No.2, Hal.99-111.

Rahmadi, Yuda Ditio. 2009. Pengaruh Earning Per Share, Arus Kas Operasi, Economic Value Added, dan Market Value Added Terhadap Return Saham (Studi Pada Perusahaan Manufaktur Yang Terdaftar Pada BEI). Skripsi. Universitas Negeri Padang.

Rudianto. 2006. Akuntansi Manajemen. Jakarta: PT Gramedia.

Savitri, Dyah Ayu. 2012. Analisis Pengaruh ROA, NPM, EPS, Dan PER Terhadap Return Saham (Studi Kasus Pada Perusahaan Manufaktur Sektor Food And Beverages Periode 2007-2010).

Universitas Skripsi Semarang.

Sugiyono. 2010. Metode Penelitian Bisnis (Pendekatan Kuantitatif dan Kualitatif). Cetakan kelimabelas.

Alfabeta.

Bandung.

Tandelilin, Enduras. 2010. Analisis Investasi dan Manajemen Portofolio. $\quad$ Edisi 1. Yogyakarta: Kanisius.

Trisnawati, Ita. 2009. Pengaruh Economic Value Added, Arus Kas Operasi, Residual Income, Earnings, Operating Laverage dan Market Value Added Terhadap Return Saham. Jurnal Bisnis dan Akuntansi. Vol 11 (1) : Hal.65-78.

Wiagustini, Ni Luh Putu. 2010. Dasardasar Manajemen Keuangan.
Volume 5 No. 2 Tahun 2018

P-ISSN 2252-5262

E-ISSN 2614-499

Denpasar. Udayana University Press.

Wiyatmini dan Michael V. Damanik. 2009. Pengaruh Economic Value Added (EVA) Dan Analisis Fundamental Terhadap Harga Saham (Studi pada Sektor Industri Perdagangan Retail). Skripsi. Universitas Gunadarma. 